\title{
Direct comparison of the in vitro and in vivo stability of DFO, DFO* and DFOcyclo* for ${ }^{89} \mathrm{Zr}$-immunoPET
}

\author{
René Raavé $^{1}$ (1) - Gerwin Sandker ${ }^{1} \cdot$ Pierre Adumeau $^{2} \cdot$ Christian Borch Jacobsen $^{3} \cdot$ Floriane Mangin $^{2} \cdot$ Michel Meyer $^{2}$. \\ Mathieu Moreau ${ }^{2}$ - Claire Bernhard ${ }^{2} \cdot$ Laurène Da Costa $^{2}$ - Adrien Dubois ${ }^{2} \cdot$ Victor Goncalves $^{2} \cdot$ Magnus Gustafsson $^{3}$. \\ Mark Rijpkema ${ }^{1}$ - Otto Boerman ${ }^{1}$. Jean-Claude Chambron ${ }^{2,4}$. Sandra Heskamp ${ }^{1}$. Franck Denat ${ }^{2}$
}

Received: 20 February 2019 / Accepted: 29 April 2019 / Published online: 3 June 2019

(C) The Author(s) 2019

\begin{abstract}
Purpose Currently, the most commonly used chelator for labelling antibodies with ${ }^{89} \mathrm{Zr}$ for immunoPET is desferrioxamine B (DFO). However, preclinical studies have shown that the limited in vivo stability of the ${ }^{89} \mathrm{Zr}$-DFO complex results in release of ${ }^{89} \mathrm{Zr}$, which accumulates in mineral bone. Here we report a novel chelator DFOcyclo*, a preorganized extended DFO derivative that enables octacoordination of the ${ }^{89} \mathrm{Zr}$ radiometal. The aim was to compare the in vitro and in vivo stability of $\left[{ }^{89} \mathrm{Zr}\right] \mathrm{Zr}$-DFOcyclo*, $\left[{ }^{89} \mathrm{Zr}\right] \mathrm{Zr}$ DFO* and $\left[{ }^{89} \mathrm{Zr}\right] \mathrm{Zr}-\mathrm{DFO}$.

Methods The stability of ${ }^{89} \mathrm{Zr}$-labelled chelators alone and after conjugation to trastuzumab was evaluated in human plasma and PBS, and in the presence of excess EDTA or DFO. The immunoreactive fraction, $\mathrm{IC}_{50}$, and internalization rate of the conjugates were evaluated using HER2-expressing SKOV-3 cells. The in vivo distribution was investigated in mice with subcutaneous HER2 ${ }^{+}$SKOV3 or HER2 ${ }^{-}$MDA-MB-231 xenografts by PET/CT imaging and quantitative ex vivo tissue analyses 7 days after injection.

Results ${ }^{89} \mathrm{Zr}$-labelled DFO, DFO* and DFOcyclo* were stable in human plasma for up to 7 days. In competition with EDTA, DFO* and DFOcyclo* showed higher stability than DFO. In competition with excess DFO, DFOcyclo*-trastuzumab was significantly more stable than the corresponding DFO and DFO* conjugates $(p<0.001)$. Cell binding and internalization were similar for the three conjugates. In in vivo studies, HER $2^{+}$SKOV-3 tumour-bearing mice showed significantly lower bone uptake $(p<0.001) 168 \mathrm{~h}$ after injection with $\left[{ }^{89} \mathrm{Zr}\right] \mathrm{Zr}$-DFOcyclo*-trastuzumab (femur $1.5 \pm 0.3 \% \mathrm{ID} / \mathrm{g}$, knee $2.1 \pm 0.4 \% \mathrm{ID} / \mathrm{g}$ ) or $\left[{ }^{89} \mathrm{Zr}\right] \mathrm{Zr}$-DFO*-trastuzumab (femur $2.0 \pm 0.3 \% \mathrm{ID} / \mathrm{g}$, knee $2.68 \pm 0.4 \% \mathrm{ID} / \mathrm{g}$ ) than after injection with $\left.{ }^{89} \mathrm{Zr}\right] \mathrm{Zr}$-DFO-trastuzumab (femur $4.5 \pm 0.6 \% \mathrm{ID} / \mathrm{g}$, knee $7.8 \pm$ $0.6 \% \mathrm{ID} / \mathrm{g}$ ). Blood levels, tumour uptake and uptake in other organs were not significantly different at $168 \mathrm{~h}$ after injection. HER2 MDA-MB-231 tumour-bearing mice showed significantly lower tumour uptake $(p<0.001)$ after injection with [ $\left.{ }^{89} \mathrm{Zr}\right] \mathrm{Zr}-\mathrm{DFOcyclo*}$ trastuzumab $(16.2 \pm 10.1 \% \mathrm{ID} / \mathrm{g})$ and $\left[{ }^{89} \mathrm{Zr}\right] \mathrm{Zr}$-DFO-trastuzumab $(19.6 \pm 3.2 \% \mathrm{ID} / \mathrm{g})$ than HER2 ${ }^{+}$SKOV-3 tumour-bearing mice $(72.1$ $\pm 14.6 \% \mathrm{ID} / \mathrm{g}$ and $93.1 \pm 20.9 \% \mathrm{ID} / \mathrm{g}$, respectively), while bone uptake was similar.
\end{abstract}

This article is part of the Topical Collection on Radiopharmacy

Electronic supplementary material The online version of this article (https://doi.org/10.1007/s00259-019-04343-2) contains supplementary material, which is available to authorized users.

Jean-Claude Chambron jcchambron@unistra.fr

$\triangle$ Sandra Heskamp Sandra.heskamp@radboudumc.nl

$\triangle$ Franck Denat franck.denat@u-bourgogne.fr

1 Department of Radiology and Nuclear Medicine, Radboudumc, Radboud Institute for Molecular Life Sciences, Nijmegen, The Netherlands
2 Institut de Chimie Moléculaire de l'Université de Bourgogne, UMR 6302, CNRS, Université Bourgogne Franche-Comté, 9 avenue A. Savary, 21078 Dijon Cedex, France

3 Global Research Technologies, Novo Nordisk A/S, Novo Nordisk Park, DK-2760 Måløv, Denmark

4 Institut de Chimie de Strasbourg, UMR 7177, CNRS, Université de Strasbourg, 1 rue Blaise Pascal, 67008 Strasbourg Cedex, France 
Conclusion ${ }^{89} \mathrm{Zr}$-labelled DFOcyclo* and DFOcyclo*-trastuzumab showed higher in vitro and in vivo stability than the current commonly used ${ }^{89} \mathrm{Zr}$-DFO-trastuzumab. DFOcyclo* is a promising candidate to become the new clinically used standard chelator for ${ }^{89} \mathrm{Zr}$ immunoPET.

Keywords ${ }^{89} \mathrm{Zr} \cdot$ immunoPET $\cdot$ DFOcyclo* $\cdot$ DFO* $\cdot$ DFO $\cdot$ Monoclonal antibodies

\section{Introduction}

${ }^{89} \mathrm{Zr}$ has shown great potential as a radionuclide for immunoPET imaging with monoclonal antibodies. ${ }^{89} \mathrm{Zr}$ has favourable characteristics: its half-life of $78.4 \mathrm{~h}$ matches the kinetics of $\mathrm{IgG}$ molecules, it is a residualizing radionuclide that provides images with high target to background ratios [1], and high PET image resolution is obtained because of the relatively low-energy positrons $\left(E_{\text {mean }}=395 \mathrm{keV}\right)$, which is not affected by its $\gamma$-emission at $909 \mathrm{keV}$. Because of these advantages it is frequently used in preference to other long-lived positron emitters, such as ${ }^{124}$ I.

Despite these favourable characteristics for immunoPET, the use of ${ }^{89} \mathrm{Zr}$ has a major drawback when used in combination with the clinically approved chelator currently used for antibody labelling, desferrioxamine B (DFO). In vivo studies have revealed that a fraction of ${ }^{89} \mathrm{Zr}$ is released from DFO, resulting in accumulation of ${ }^{89} \mathrm{Zr}$ in mineral bone [2-6]. This may hamper the detection of bone metastases, an undesired radiation dose to bone marrow, and overestimation of the radiation dose to the red marrow in radionuclide therapy dose planning. Release of ${ }^{89} \mathrm{Zr}$ from DFO is the result of suboptimal complexation. ${ }^{89} \mathrm{Zr}^{4+} \mathrm{de}-$ mands octacoordination to form stable complexes, while the three hydroxamate groups of DFO only offer hexacoordination, resulting in additional binding of water molecules to saturate the coordination sphere of ${ }^{89} \mathrm{Zr}^{4+}[5]$. Eventually this can result in the release of ${ }^{89} \mathrm{Zr}$, which may subsequently accumulate in mineral bone $[5,7]$.

To overcome the limited stability of the $\left[{ }^{89} \mathrm{Zr}\right] \mathrm{Zr}$-DFO complex, alternative chelators for $\left.{ }^{89} \mathrm{Zr}\right] \mathrm{Zr}^{4+}$ have been developed [8-10]. Examples are DFO derivatives such as DFO* [11] and other "extended" DFO analogues [12], or DFO squaramide ester [13]. Macrocyclic compounds with three or four hydroxamic acid groups [14-16], and chelating agents based on hydroxypyridinone, terephthalamide or catecholate groups as alternatives to hydroxamate-based chelators have also been evaluated [17-24]. Furthermore, the well-known chelator 1,4,7,10tetraazacyclododecane-1,4,7,10-tetraacetic acid $\left(\mathrm{H}_{4} \mathrm{DOTA}\right)$ has also been found to chelate $\left.{ }^{[89} \mathrm{Zr}\right] \mathrm{Zr}^{4+}$ very efficiently. However, in the absence of an improved, clinically applicable chelator, there is room for more efficient $\left[{ }^{89} \mathrm{Zr}\right] \mathrm{Zr}^{4+}$ chelators.

In a quest for a more stable $\mathrm{Zr}^{4+}$ chelate, we have developed a new bifunctional DFO derivative, DFOcyclo*-pPhe-NCS. By addition of a fourth hydroxamic acid cyclic group, an octadentate DFO derivative with the expected $\mathrm{Zr}^{4+}$ coordination properties was synthesized. The in vitro stability of radiolabelled DFOcyclo* was compared with that of radiolabelled DFO and
DFO*. Subsequently, all three chelators were conjugated to trastuzumab (Herceptin) by random isothiocyanate-based conjugation, and the in vivo stability of the conjugates was evaluated in tumour-bearing nude mice. Finally, in an attempt to elucidate the mechanism of ${ }^{89} \mathrm{Zr}$ release from DFO, the hypothesis that ${ }^{89} \mathrm{Zr}$ is released from its chelate upon internalization by cancer cells was tested using a HER2-negative tumour model.

\section{Materials and methods}

\section{Reagents and equipment specifications}

All chemicals, unless otherwise noted, were purchased from Sigma-Aldrich, and used as received without further purification. Ultrapure water produced by a PURELAB Ultra system from ELGA was used throughout (18.2 $\mathrm{M} \Omega \mathrm{cm}$ ). NMR spectra were acquired on a Bruker Avance III HD spectrometer operating at $600 \mathrm{MHz}$. The conjugates were purified by FPLC on an Äkta Pure $25 \mathrm{M}$ chromatography system (GE Healthcare Life Sciences). MALDI-TOF mass spectra were acquired on an ultrafleXtreme instrument (Bruker Daltonics). Size-exclusion chromatography (SEC-HPLC) analyses were performed on a JASCO HPLC system LC-2000 analytical series equipped with a Superdex 200 5/150 GL column. Instant thin-layer chromatography (iTLC) was performed using sheets impregnated with salicylic acid (iTLC-SA; Agilent) eluted with 0.1 M EDTA, $\mathrm{pH}$ 5.0, and analysed on an AR-2000 radio-TLC plate reader (Bioscan Inc.). PET/CT scans were acquired on an Inveon animal PET scanner (Siemens Preclinical Solutions).

\section{Synthesis of chelators}

DFO- $p$ Phe-NCS was provided by Chematech. DFO* was synthesized according to a previously described procedure [25], with slight modifications enabling isolation of the desired compound in good yield without the need for cumbersome purifications. Likewise, the preparation of DFO*- $p$ PheNCS was adapted from a previously described procedure [25]. DFOcyclo*- $p$ Phe-NCS will soon become commercially available, but in the meantime samples can be obtained from the authors upon request. Briefly, DFOcyclo*-pPhe-NCS was obtained by hemisynthesis in three steps from commercially obtained Desferal and a functionalized 1-hydroxypiperidine-2one (1,2-PIPOH) derivative [26]. After benzyl deprotection under $\mathrm{H}_{2}$ on $\mathrm{Pd} / \mathrm{C}$, the functionalized tetrachelate was reacted 
in a final step with a large excess of $p$-phenylene diisothiocyanate (PDITC), and the reaction was stopped at an early stage to favour single condensation. DFOcyclo*$p$ Phe-NCS was obtained in $14 \%$ isolated yield after direct injection of the crude reaction mixture onto a semipreparative HPLC column and elution with water/acetonitrile/formic acid with a gradient of 70:30:0.1 to 30:70:0.1. The compound was fully characterized and identified by ${ }^{1} \mathrm{H}$ NMR spectroscopy (Supplementary Figs. 1-3), HR-ESI-MS (Supplementary Figs. 4-6), and analytical HPLC (Supplementary Fig. 6).

\section{${ }^{89} \mathrm{Zr}$ radiolabelling of chelates}

To $25 \mu \mathrm{L} 1 \mathrm{M}$ HEPES (pH 7.4) was added $2.5 \mu \mathrm{L}$ of a $1 \mathrm{mM}$ solution of chelator in water. To this solution was added $5 \mathrm{MBq}$ of $\left.\left[{ }^{89} \mathrm{Zr}\right][\mathrm{Zr} \text { (oxalate })_{4}\right]^{4-}$ adjusted to $\mathrm{pH} 7.4$ with $2 \mathrm{M}$ $\mathrm{Na}_{2} \mathrm{CO}_{3}$. The mixture was incubated at room temperature for $15 \mathrm{~min}$. The progress of the reaction was then assayed using iTLC, and complete chelation was observed.

\section{Stability of the chelates in human plasma and EDTA challenge}

The radiochemical purity and the stability of the ${ }^{89} \mathrm{Zr}$-labelled chelates was assessed in plasma and in the presence of EDTA, either by adding $1.5 \mathrm{MBq}$ of radiolabelled chelate to $200 \mu \mathrm{L}$ of human plasma or by adding 1,000 equivalents of EDTA to $1 \mathrm{MBq}$ of the radiolabelled chelate diluted to $50 \mu \mathrm{L}$ with PBS. The mixtures were incubated at $37^{\circ} \mathrm{C}$. Aliquots were analysed by iTLC-SA after 24, 48, 72, 96 and $168 \mathrm{~h}$. All samples were prepared in triplicate.

\section{Determination of the partition coefficient of the radiolabelled chelates}

The $\log D$ values of the radiolabelled chelates (in their $-\mathrm{NH}_{2}$ version) were determined using an $n$-octanol/PBS (pH 7.4) system. The radiolabelled chelate $(10 \mu \mathrm{L}, 0.5 \mathrm{MBq})$ was added to $1 \mathrm{~mL}$ of PBS, $\mathrm{pH}$ 7.4. This solution was supplemented with $1 \mathrm{~mL}$ of $n$-octanol previously saturated with water. The mixture was vigorously stirred for $20 \mathrm{~min}$ at $25^{\circ} \mathrm{C}$. The two layers were then separated by centrifugation and $50 \mu \mathrm{L}$ of each layer was collected and counted in an automatic Wizard $\gamma$-counter (PerkinElmer). All samples were measured in triplicate. The partition coefficient $D$ was calculated using the following formula: $\log D=\log \left(A_{\text {oct }} / A_{\mathrm{PBS}}\right)$, where $A_{\text {oct }}$ and $A_{\mathrm{PBS}}$ are the activity of the $n$-octanol and PBS layer, respectively.

\section{Trastuzumab conjugation}

Bifunctional chelator (30 equivalents, $51.5 \mu \mathrm{L}$ of a $20 \mathrm{mM}$ stock solution in DMSO) was added to $5.0 \mathrm{mg}$ of purified trastuzumab (in solution at $4 \mathrm{mg} / \mathrm{mL}$ in $0.2 \mathrm{M}$ sodium bicarbonate buffer
(pH 8.4 buffer for DFO- $p$ Phe-NCS and DFOcyclo*- $p$ PheNCS conjugation) and $0.1 \mathrm{M}$ borate buffer ( $\mathrm{pH} 9.5$ buffer for DFO* ${ }^{*} p$ Phe-NCS conjugation; Fig. 1). The reaction mixture was stirred at $900 \mathrm{rpm}$ overnight at $37{ }^{\circ} \mathrm{C}$. The mixture was purified by FPLC. Excess chelator was washed away with phosphate buffer $(20 \mathrm{mM}, \mathrm{pH} 7.3)$ and the conjugate was eluted with $50 \mathrm{mM}$ acetate buffer (pH 3.0), and subsequently the buffer was changed to PBS, $\mathrm{pH} 7.4$, in an ultracentrifugal filter device (Amicon Ultra $2 \mathrm{~mL}$, Ultracel cut-off $30 \mathrm{kDa}$; Merck Millipore). The protein recovery rate was $>89 \%$.

\section{${ }^{89} \mathrm{Zr}$ radiolabelling of conjugates}

To $100 \mu \mathrm{L}$ of $1 \mathrm{M}$ HEPES, pH 7.3, were added $500 \mu \mathrm{g}$ of trastuzumab conjugate in PBS, $\mathrm{pH}$ 7.4. To this solution were added $25 \mathrm{MBq}$ of a $\left.{ }^{89} \mathrm{Zr}\right]\left[\mathrm{Zr}(\text { oxalate })_{4}\right]^{4-}$ solution adjusted to $\mathrm{pH} 7.4$ with $2 \mathrm{M} \mathrm{Na}_{2} \mathrm{CO}_{3}$. The mixture was incubated at room temperature for $30 \mathrm{~min}$. The progress of the reaction was assayed using iTLC, and complete chelation was observed. The radiolabelled conjugate was purified and concentrated using centrifugal filtration units with a $30 \mathrm{kDa}$ molecular weight cut-off filter (Amicon Ultra $0.5 \mathrm{~mL}$; Centrifugal Filtration Units, Merck Millipore). Prior to in vivo injection, ${ }^{89} \mathrm{Zr}$-labelled trastuzumab conjugates were purified by elution on prewashed PD-10 desalting columns (GE Healthcare Life Sciences) eluted with PBS ( $\mathrm{pH} 7.4$ ), instead of purification and concentration using centrifugal filtration units.

\section{Stability studies of conjugates}

\section{EDTA challenge of the radiolabelled conjugates}

The stability of the conjugates in the presence of EDTA was assessed by adding 1,000 equivalents of EDTA to 0.3$0.5 \mathrm{MBq}$ of the conjugate and diluting the mixture to $50 \mu \mathrm{L}$ with PBS. The mixture was incubated at $37^{\circ} \mathrm{C}$. Aliquots were analysed by iTLC-SA after 24, 48, 72, 96 and $168 \mathrm{~h}$. All samples were prepared in triplicate.

\section{DFO challenge of the radiolabelled conjugates}

To assess the stability of the conjugates in the presence of DFO, 2-2.5 MBq of the conjugate was supplemented with 1,000 equivalents of DFO and diluted to $50 \mu \mathrm{L}$ with PBS. The mixture was incubated at $37^{\circ} \mathrm{C}$. Aliquots were analysed by size-exclusion chromatography after 1, 4, 8, 12, 24 and $48 \mathrm{~h}$. All samples were prepared in triplicate.

\section{Cell culture}

The HER2 ${ }^{+}$human ovarian cancer cell line SKOV-3 (HTB-77; ATCC) and the HER2 ${ }^{-}$human breast cancer cell line MDAMB-231 (HTB-26; ATCC) were cultured in RPMI-1640 


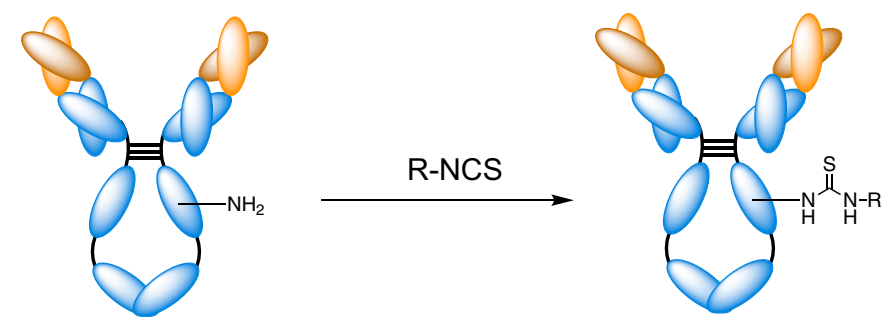

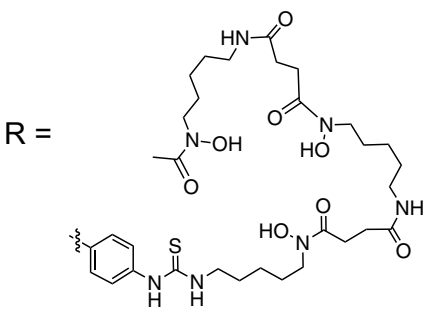

DFO

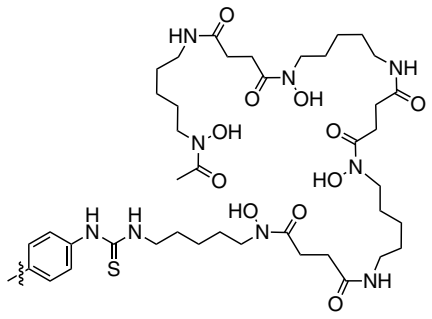

DFO*

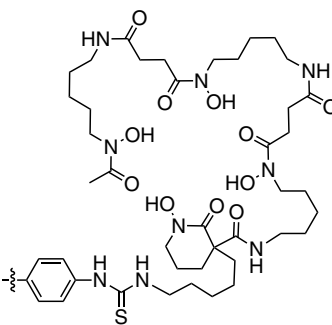

DFO-cyclo*

Fig. 1 Molecular structures of the conjugates considered in this work: DFO-trastuzumab, DFO*-trastuzumab, and DFOcyclo*-trastuzumab

medium (Gibco, ThermoFisher Scientific, Waltham, MA, USA) supplemented with $2 \mathrm{mM}$ glutamine (Gibco) and $10 \%$ fetal calf serum (Sigma-Aldrich Chemie BV), at $37{ }^{\circ} \mathrm{C}$ in a humidified atmosphere containing $5 \% \mathrm{CO}_{2}$. Cells were dissociated when $80-90 \%$ confluency was reached using $0.05 \%$ trypsin (w/v) in $0.53 \mathrm{mM}$ EDTA (Life Technologies) and maintained as proliferating cultures. Mycoplasma contamination was evaluated every 4 months using a MycoAlert mycoplasma detection kit (Lonza, Basel, Switzerland). After thawing, cells were maintained in culture for a maximum of 6 months.

\section{Binding and internalization assay}

The binding and internalization kinetics of trastuzumab conjugated with DFO, DFO* and DFOcyclo* labelled with ${ }^{89} \mathrm{Zr}$ were tested using SKOV-3 cells and MDA-MB-231 cells. Cells $\left(0.5 \times 10^{6}\right.$ cells/well $)$ were cultured in six-well plates and incubated with $250 \mathrm{pM}^{89} \mathrm{Zr}$-labelled DFO-trastuzumab, DFO*-trastuzumab or DFOcyclo*-trastuzumab in $0.5 \% \mathrm{BSA} /$ RPMI-1640 medium (w/v) for 1, 4 and $24 \mathrm{~h}$. Nonspecific binding and internalization was determined by coincubation with $500 \mathrm{nM}$ unlabelled trastuzumab. The membrane-bound fraction was removed from the cells by incubation in an icecold solution containing $0.1 \mathrm{M}$ acetic acid and $154 \mathrm{mM} \mathrm{NaCl}$, $\mathrm{pH}$ 2.6, for $10 \mathrm{~min}$. Cells were harvested by incubation in $0.1 \mathrm{M} \mathrm{NaOH}$ for $5 \mathrm{~min}$. Binding and internalization were determined by counting the radioactivity using a gamma counter (Wizard, PerkinElmer).

\section{Immunoreactive fraction}

The immunoreactive fraction of ${ }^{89} \mathrm{Zr}$-labelled trastuzumab was determined as described by Lindmo et al. [27]. In brief, a serial dilution of SKOV-3 cells ranging from $2.5 \times 10^{6}$ to
$1.56 \times 10^{5}$ cells in $0.5 \mathrm{ml}$ were incubated with $250 \mathrm{pM}^{89} \mathrm{Zr}$ labelled DFO-trastuzumab, DFO*-trastuzumab, or DFOcyclo*-trastuzumab at $37{ }^{\circ} \mathrm{C}$ for $30 \mathrm{~min}$. Nonspecific binding was determined by incubation of $1.56 \times 10^{6}$ cells with an excess of nonlabelled trastuzumab $(500 \mathrm{nM})$. After incubation, cells were washed twice and the radioactivity in the cell pellet was measured using a gamma counter (Wizard, PerkinElmer).

\section{In vivo stability studies}

\section{Animals}

The Dutch Central Committee on Animal Research and the local Ethics Committee on Animal Research of Radboud University approved this study under protocol 2015-0071. All animal experiments were performed according to institutional guidelines. Upon arrival, female BALB/cAnNRjFoxn $1^{\mathrm{nu}} /$ Foxn $1^{\mathrm{nu}}$ mice at $6-8$ weeks of age (Janvier Labs, France) were randomly tattooed for identification and were acclimatized for $\geq 4$ days before any experimental procedure. Mice had unlimited access to food and water and were maintained with five or six mice per cage in a controlled environment $\left(22 \pm 1{ }^{\circ} \mathrm{C}, 55 \pm 10 \%\right.$ humidity, 12-h dark/light cycle). Cages were replaced weekly with clean cages. Mice were assessed daily for welfare and tumour sizes were measured twice a week after tumour inoculation. Mice were randomly allocated to the experimental groups according to a random sequence generator and the biotechnicians performing the experiments were blinded to the group allocation. Tumours were inoculated by subcutaneous (s.c.) injection of $5 \times 10^{6} \mathrm{SKOV}-3$ or MDA-MB-231 cells mixed 2:1 or 1:1 in Matrigel (BD Biosciences; Pharmingen), respectively. Experiments were started when tumours had reached a size of $0.4-0.5 \mathrm{~mm}^{3}$. 


\section{In vivo stability studies}

In a first experiment, the in vivo stability of $\left[{ }^{89} \mathrm{Zr}\right] \mathrm{Zr}$ DFOcyclo*-trastuzumab was compared with that of $\left[{ }^{89} \mathrm{Zr}\right] \mathrm{Zr}$-DFO-trastuzumab. SKOV-3 tumour-bearing mice were injected with $\left.200 \mu \mathrm{L}(750 \mathrm{kBq}){ }^{89} \mathrm{Zr}\right] \mathrm{Zr}$-DFOtrastuzumab and $\left[{ }^{89} \mathrm{Zr}\right] \mathrm{Zr}$-DFOcyclo*-trastuzumab, together with $85 \mu \mathrm{g}$ nonradiolabelled trastuzumab (Herceptin, Roche) to a total of $100 \mu \mathrm{g}$ trastuzumab. The ex vivo biodistribution of the ${ }^{89} \mathrm{Zr}$-labelled conjugates was determined by killing the mice by $\mathrm{CO}_{2} / \mathrm{O}_{2}$ asphyxiation at $24 \mathrm{~h}$ (five mice per group), $72 \mathrm{~h}$ (five mice) and $168 \mathrm{~h}$ (six mice) after injection, and collecting tumour, blood, muscle, heart, lung, spleen, pancreas, kidney, liver, stomach, duodenum, colon, salivary glands, sternum, femur, knee and bone marrow. To determine the blood kinetics, blood samples were collected at 1, 3, 24, 72 and $168 \mathrm{~h}$ after injection via a tail vein (live mice) or by heart puncture (killed mice) ${ }^{89} \mathrm{Zr}$ radioactivity was quantified in the collected samples using a gamma counter (Wizard, PerkinElmer) and expressed as percentage of injected dose per gram of tissue $(\% \mathrm{ID} / \mathrm{g})$, calculated from the amount of radioactivity measured in aliquots of the injected dose. Simultaneously, mice bearing HER2 ${ }^{-}$MDA-MB-231 s.c. tumours (six mice per group) were also injected with $200 \mu \mathrm{L}$ $(750 \mathrm{kBq})\left[{ }^{89} \mathrm{Zr}\right] \mathrm{Zr}$-DFO-trastuzumab or $\left[{ }^{89} \mathrm{Zr}\right] \mathrm{Zr}$ DFOcyclo*-trastuzumab to investigate whether $\left[{ }^{89} \mathrm{Zr}\right] \mathrm{Zr}^{4+}$ is released from its chelate upon HER2-mediated internalization by cancer cells. Blood kinetics and ex vivo biodistribution analyses were performed as described above.

In a second experiment, the in vivo stability of $\left[{ }^{89} \mathrm{Zr}\right] \mathrm{Zr}$ DFO-trastuzumab and $\left[{ }^{89} \mathrm{Zr}\right] \mathrm{Zr}$-DFOcyclo*-trastuzumab was compared with that of $\left[{ }^{89} \mathrm{Zr}\right] \mathrm{Zr}$-DFO*-trastuzumab, a promising recently described $\left[{ }^{89} \mathrm{Zr}\right] \mathrm{Zr}^{4+}$ chelate [25]. SKOV-3 s.c. tumour-bearing mice were injected with $200 \mu \mathrm{L}(5 \mathrm{MBq})$ $\left[{ }^{89} \mathrm{Zr}\right] \mathrm{Zr}$-DFO-trastuzumab (five mice per group), $\left[{ }^{89} \mathrm{Zr}\right] \mathrm{Zr}$ DFOcyclo*-trastuzumab (six mice) and $\left.{ }^{89} \mathrm{Zr}\right] \mathrm{Zr}$-DFO*trastuzumab (six mice) together with 5,11 and $10.3 \mu \mathrm{g}$ of nonradiolabelled trastuzumab to a total of $100 \mu \mathrm{g}$ trastuzumab for DFO-trastuzumab, DFOcyclo*-trastuzumab and DFO*trastuzumab, respectively. Two mice from each group were randomly selected for PET imaging. Mice were imaged under general anaesthesia $\left(2-3 \%\right.$ isoflurane $/ \mathrm{O}_{2}$ ) for $20 \mathrm{~min}$ at 24 and $72 \mathrm{~h}$ after injection. PET scans were followed by a CT scan for anatomic reference (spatial resolution of $113 \mu \mathrm{m}, 80 \mathrm{kV}$, and $500 \mu \mathrm{A})$. Scans were reconstructed using Inveon Acquisition Workplace software with iterative three-dimensional ordered subsets expectation maximization using a maximum a priori algorithm with shifted Poisson distribution, with the following parameters: matrix $256 \times 256 \times 161$, pixel size $0.4 \times 0.4 \times$ $0.8 \mathrm{~mm}$, with a corresponding beta of $0.05 \mathrm{~mm}$. At $168 \mathrm{~h}$ after injection, mice were killed and imaged for $30 \mathrm{~min}$. Subsequently, the biodistribution of the three ${ }^{89} \mathrm{Zr}$-labelled conjugates was determined ex vivo as described before.
Blood kinetics were determined in live mice as described above at 1, 3, 24 and $72 \mathrm{~h}$ after injection.

\section{Statistical analysis}

Statistical analysis was performed using GraphPad Prism version 5.03 for Windows. Differences in ${ }^{89} \mathrm{Zr}$ tissue uptake were tested for significance using Student's $t$-test or one-way ANOVA with a Bonferroni's post-hoc test.

\section{Results}

\section{Chelator structure}

DFOcyclo* is an analogue of DFO*. Both chelators contain four hydroxamate moieties, instead of only three for DFO. The main difference between DFO* and DFOcyclo* is the cyclic structure of the additional hydroxamic acid group derived from 1,2-PIPOH. While open-chain hydroxamic acids, including DFO, are known to exist as a mixture of two $E$ (trans) and $Z$ (cis) isomers [28-30], the $Z$ configuration of the hydroxamate group is imparted by the cyclic structure of $\mathrm{PIPO}^{-}$, and is obviously more favourable for $\mathrm{Zr}^{4+}$ coordination and could therefore result in a more stable complex [31]. The crystal structure of a $\mathrm{Zr}^{4+}$ complex in which the metal is co-

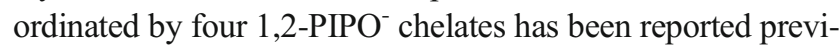
ously [32].

The chemical structure of DFOcyclo*- $p$ Phe-NCS, the immediate precursor of the DFOcyclo*-trastuzumab bioconjugate, was established by NMR (Supplementary Figs. 1-3) and HR-ESI-MS spectroscopy (Supplementary Figs. 4-5). The ${ }^{1} \mathrm{H}$ NMR spectrum in DMSO- $d_{6}$ showed the characteristic signals of DFO, the PIPOH additional chelate, and the isothiocyanate-functionalized tether (Supplementary Fig. 1). Noticeably, all the heteroatom-bound hydroxamic (H1, H15, $\mathrm{H} 26, \mathrm{H} 37)$, amide (H9, H20, H31) and thiourea (H44, H45) protons could be located in the ${ }^{1} \mathrm{H}$ NMR spectrum. The hydroxamic protons and the thiourea proton $\mathrm{H} 45$ appeared as broad singlets in the low-field region of the spectrum $\left(>9.5 \mathrm{ppm}\right.$ in DMSO- $d_{6}$ ), while the aliphatic amide protons appeared at $7.5-8 \mathrm{ppm}$ as well-resolved triplets, together with the doublets of the aromatic protons (H46, H47). As shown by the ROESY map, the hydroxamic protons exchanged with water protons, and showed multiple correlations with their neighbours (Supplementary Fig. 2). This information was very valuable for the assignment of the signals of the aliphatic protons, which showed multiple overlaps. In this way, aliphatic protons of the PIPOH fragment (H4, H5, H6), of the DFO backbone (H10-H14, H17, H18, H21-H25, H28, H29, H32-H36, H39), and of the aliphatic tether $(\mathrm{H} 7, \mathrm{H} 40-\mathrm{H} 43)$ could be assigned without any ambiguity (Supplementary Fig. 3). 

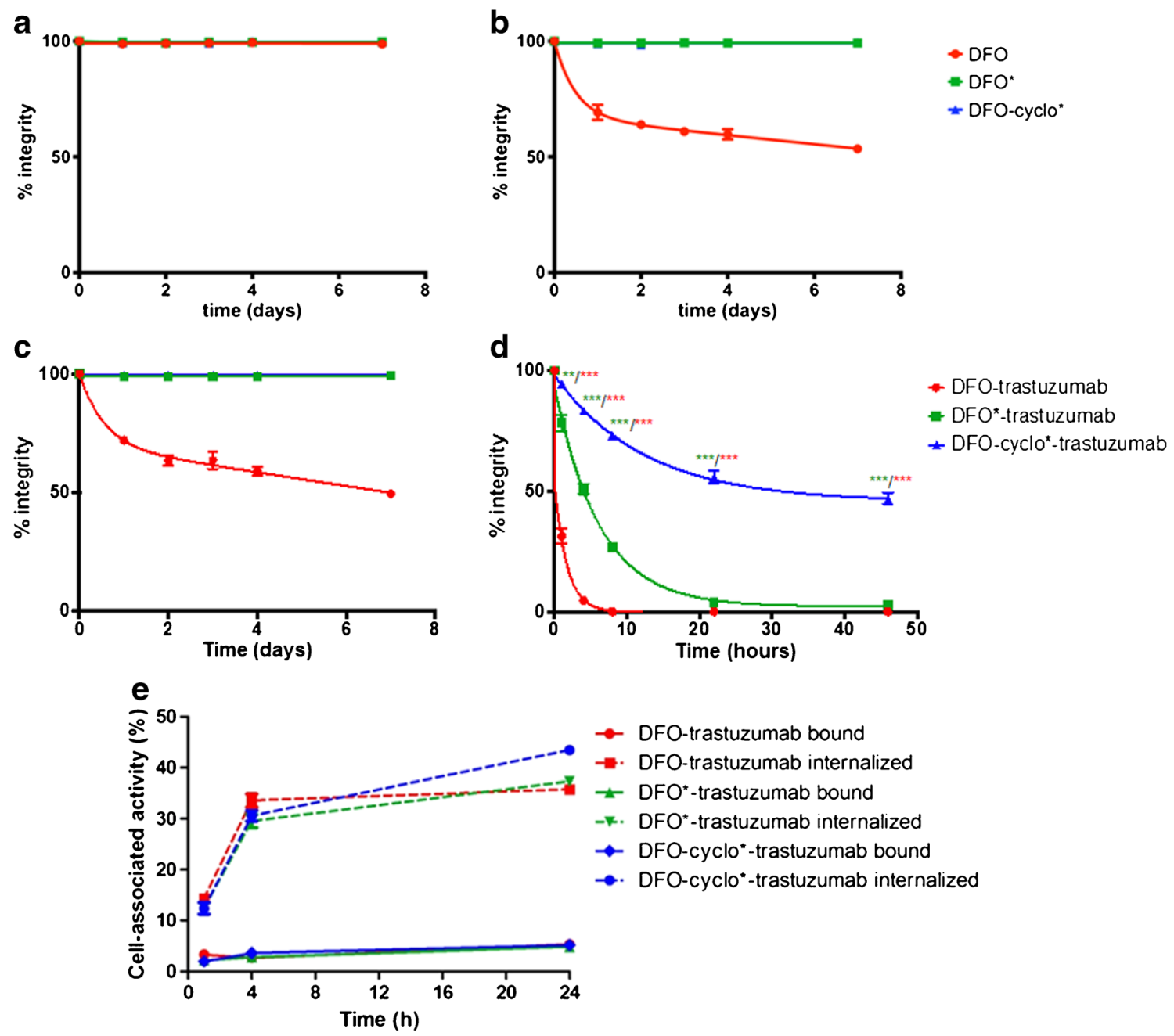

Fig. 2 Stability of $\left[{ }^{89} \mathrm{Zr}\right] \mathrm{Zr}-\mathrm{DFO}$ (red), $\left[{ }^{89} \mathrm{Zr}\right] \mathrm{Zr}-\mathrm{DFO} *$ (green) and $\left[{ }^{89} \mathrm{Zr}\right] \mathrm{Zr}$-DFOcyclo* (blue) in human plasma (a) and in the presence of 1,000 equivalents of EDTA (b) at $37{ }^{\circ} \mathrm{C}$. Stability of $\left[{ }^{89} \mathrm{Zr}\right] \mathrm{Zr}$-DFOtrastuzumab (red), $\left[{ }^{89} \mathrm{Zr}\right] \mathrm{Zr}$-DFO*-trastuzumab (green) and $\left[{ }^{89} \mathrm{Zr}\right] \mathrm{Zr}$ DFOcyclo*-trastuzumab (blue) in the presence of 1,000 equivalents of

\section{Partition coefficient of the radiolabelled chelates}

There was no significant difference in the octanol/water partition coefficient between the $\left[{ }^{89} \mathrm{Zr}\right] \mathrm{Zr}-\mathrm{DFO}-\mathrm{NH}_{2}$ and the $\left[{ }^{89} \mathrm{Zr}\right] \mathrm{Zr}$-DFO*-NH${ }_{2}$ chelates $(\log D-3.61 \pm 0.21$ and -3.54 \pm 0.16 , respectively). However, DFOcyclo* exhibited a slightly more lipophilic behaviour than DFO and DFO* $(\log D$ $-2.14 \pm 0.10$ for $\left[{ }^{89} \mathrm{Zr}\right] \mathrm{Zr}$-DFOcyclo*- $\mathrm{NH}_{2}$ ) due to the addition of the piperidine ring.

\section{Conjugation trastuzumab substitution ratio}

The degree of labelling of the conjugates DFO-trastuzumab, DFOcyclo*-trastuzumab and DFO*-trastuzumab was determined by mass spectrometry. The values obtained ranged from 2.6 to 4.7 for DFO-trastuzumab, and were 3.7 and 2.6
EDTA (c) and 1,000 equivalents of DFO (d) at $37{ }^{\circ} \mathrm{C}$. Bound and internalized conjugates in HER $2^{+}$SKOV-3 cells after 1,4 and $24 \mathrm{~h}$ of incubation (e). Error bars represent standard deviations. $* * p<0.01$, $* * * p<0.001$

for DFOcyclo*-trastuzumab and $\mathrm{DFO}^{*}$-trastuzumab, respectively.

\section{Chelate/conjugate labelling, specific activity and stability}

The chelators were quantitatively labelled with specific activities reaching $4 \mathrm{MBq} / \mathrm{nmol}$. All chelates remained stable in plasma after 7 days (Fig. 2a). Importantly, $\left[{ }^{89} \mathrm{Zr}\right] \mathrm{Zr}-\mathrm{DFO} *$ and $\left[{ }^{89} \mathrm{Zr}\right] \mathrm{Zr}$-DFOcyclo* showed higher stability than $\left[{ }^{89} \mathrm{Zr}\right] \mathrm{Zr}$-DFO in the presence of excess EDTA. The integrity of $\left[{ }^{89} \mathrm{Zr}\right] \mathrm{Zr}$-DFO decreased to $53 \%$, while the $\left[{ }^{89} \mathrm{Zr}\right] \mathrm{Zr}$-DFO* and $\left[{ }^{89} \mathrm{Zr}\right] \mathrm{Zr}$-DFOcyclo* complexes remained $>98 \%$ intact after 7 days (Fig. 2b).

The conjugates were quantitatively labelled at a specific activity of $50 \mathrm{GBq} / \mathrm{g}(7.5 \mathrm{MBq} / \mathrm{nmol})$. Size-exclusion chromatography revealed the presence of aggregates in small 

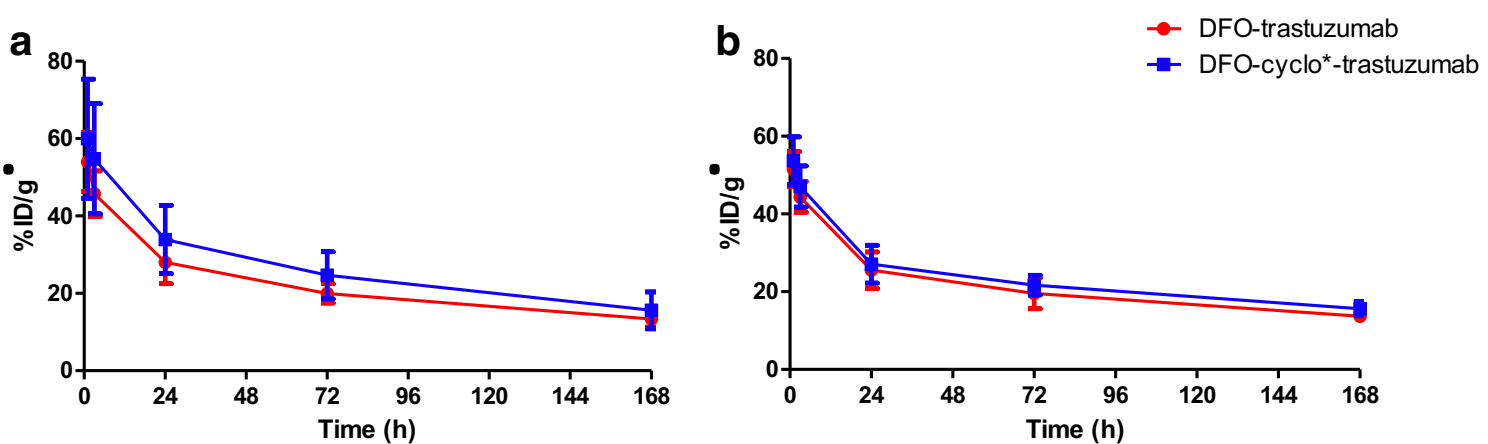

Fig. 3 Blood kinetics of $\left[{ }^{89} \mathrm{Zr}\right] \mathrm{Zr}$-DFO-trastuzumab (red) and $\left[{ }^{89} \mathrm{Zr}\right] \mathrm{Zr}$-DFOcyclo*-trastuzumab (blue) in HER2 ${ }^{+}$SKOV-3 tumour-bearing mice (a) and HER2 ${ }^{-}$MDA-MB-231 tumour-bearing mice (b). Error bars represent standard deviations

amounts for the three radioconjugates: $4.7 \pm 0.3 \%, 3.6 \pm 0.2 \%$ and $6.5 \pm 0.7 \%$ for $\left[{ }^{89} \mathrm{Zr}\right] \mathrm{Zr}$-DFOcyclo*-trastuzumab, $\left[{ }^{89} \mathrm{Zr}\right] \mathrm{Zr}$-DFO-trastuzumab and $\left[{ }^{89} \mathrm{Zr}\right] \mathrm{Zr}$-DFO*-trastuzumab, respectively. This aggregation was probably because of the choice of the bioconjugation moiety, as phenylisothiocyanate is known to cause aggregation [33, 34]. Like the free chelates, the ${ }^{89} \mathrm{Zr}$-labelled DFO*- and DFOcyclo*based conjugates showed higher stability than the DFObased conjugate. The competition experiments with EDTA gave results similar to those with the chelates alone (Fig. 2c). However, incubation of the radiolabelled conjugates with DFO clearly discriminated the stability of the three conjugates (Fig. 2d). While the integrity of $\left[{ }^{89} \mathrm{Zr}\right] \mathrm{Zr}$-DFO*-trastuzumab decreased to $50 \%$ in $\left.4 \mathrm{~h},{ }^{89} \mathrm{Zr}\right] \mathrm{Zr}$-DFOcyclo*-trastuzumab reached $50 \%$ of integrity in $48 \mathrm{~h}$, and seemed to plateau around 50\% integrity, suggesting a much higher stability for this radiolabelled conjugate. The DFO-based conjugate exhibited the lowest stability, with an almost total release of radionuclide in less than $10 \mathrm{~h}$.

\section{In vitro assays}

The cell binding and internalization assay using HER $2^{+}$ SKOV-3 cells showed $2-4 \%$ binding for the three conjugates at 1 and $4 \mathrm{~h}$, and approximately $4-5 \%$ at $24 \mathrm{~h}$ (Fig. 2e). Internalization of the three conjugates in HER $2^{+}$SKOV-3 cells was about $12-14 \%$ at $1 \mathrm{~h}$, and increased to approximately $30-40 \%$ at 4 and $24 \mathrm{~h}$ (Fig. 2e). Incubation with an excess of nonradiolabelled trastuzumab or incubation with HER2 ${ }^{-}$ MDA-MB-231 cells resulted in binding and internalization of the three conjugates of $<1 \%$ at all time points (Supplementary Fig. 7). The immunoreactive fraction of all three conjugates was $>90 \%$.

\section{Pharmacokinetics and biodistribution of the radiolabelled conjugates in HER2 ${ }^{+}$ tumour-bearing mice}

The in vivo characteristics of $\left[{ }^{89} \mathrm{Zr}\right] \mathrm{Zr}-\mathrm{DFO}$ trastuzumab and $\left[{ }^{89} \mathrm{Zr}\right] \mathrm{Zr}$-DFOcyclo*-trastuzumab were determined by intravenous injection into HER $2^{+}$ SKOV-3 s.c. tumour-bearing nude mice. Blood levels determined at 1, 3, 24, 72 and $168 \mathrm{~h}$ after injection showed similar patterns for both conjugates (Fig. 3a). Tumour uptake increased from $26.2 \pm 3.6 \% \mathrm{ID} / \mathrm{g}$ and $39.4 \pm 12.7 \% \mathrm{ID} / \mathrm{g}$ at $24 \mathrm{~h}$ after injection to $93.1 \pm$ $20.9 \% \mathrm{ID} / \mathrm{g}$ and $72.1 \pm 14.6 \% \mathrm{ID} / \mathrm{g}$ at $168 \mathrm{~h}$ after injection for $\left[{ }^{89} \mathrm{Zr}\right] \mathrm{Zr}$-DFO-trastuzumab and $\left[{ }^{89} \mathrm{Zr}\right] \mathrm{Zr}$ DFOcyclo*-trastuzumab, respectively, but was not significantly different between the conjugates (Fig. 4a-c). Bone uptake was significantly lower in mice injected with $\left[{ }^{89} \mathrm{Zr}\right] \mathrm{Zr}$-DFOcyclo*-trastuzumab at $72 \mathrm{~h}$ after administration (femur $p<0.05$, knee $p<0.001$; Fig. 4b). At $168 \mathrm{~h}$ after injection, ${ }^{89} \mathrm{Zr}$ uptake was significantly lower in the sternum $(p<0.01)$, femur $(p<0.0001)$ and knee $(p<0.0001)$ in mice injected with $\left[{ }^{89} \mathrm{Zr}\right] \mathrm{Zr}$ DFOcyclo*-trastuzumab than in mice injected with $\left[{ }^{89} \mathrm{Zr}\right] \mathrm{Zr}$-DFO-trastuzumab. Uptake in muscle and pancreas was significantly higher in mice injected with ${ }^{89} \mathrm{Zr}$-DFOcyclo*-trastuzumab at $24 \mathrm{~h}$ after injection $(p<0.05)$, but was not different at 72 and $168 \mathrm{~h}$ after injection (Fig. 4a-c). Uptake in other organs was not significantly different for the two conjugates.

\section{In vivo blood kinetics and biodistribution in HER2 tumour-bearing mice}

To investigate the hypothesis that ${ }^{89} \mathrm{Zr}$ is released from the chelator after cellular internalization, two groups of mice bearing HER2 ${ }^{-}$MDA-MB-231 s.c. tumours were injected with $\left.750 \mathrm{kBq}(100 \mu \mathrm{g}){ }^{89} \mathrm{Zr}\right] \mathrm{Zr}$-DFO-trastuzumab or $\left[{ }^{89} \mathrm{Zr}\right] \mathrm{Zr}-$ DFOcyclo*-trastuzumab. Blood levels determined at 1,3 , 24, 72 and $168 \mathrm{~h}$ after injection showed a pattern similar to the kinetics in mice with HER2 ${ }^{+}$tumours (Fig. $3 b$ ). Ex vivo biodistribution showed a significantly lower uptake in HER $2^{-}$ tumours than in HER $2^{+}$tumours for both conjugates $(p<0.001$; Fig. $4 \mathrm{c}, \mathrm{d}){ }^{89} \mathrm{Zr}$ uptake in bone (sternum, femur and knee) in HER $2^{-}$tumour-bearing mice was comparable to that in HER2 $2^{+}$tumour-bearing mice: in both groups bone 


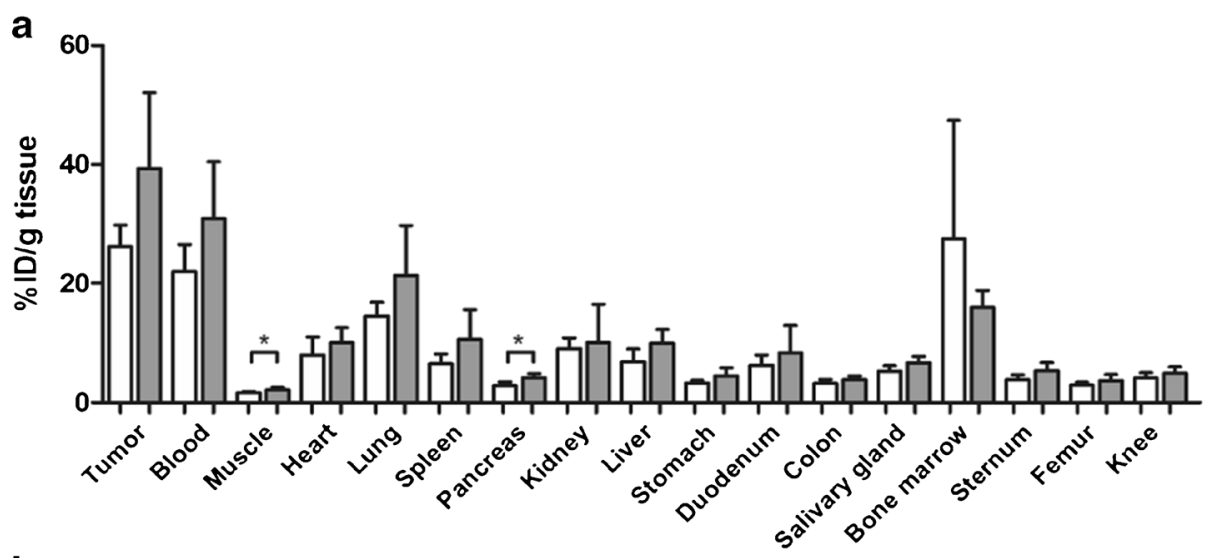

b

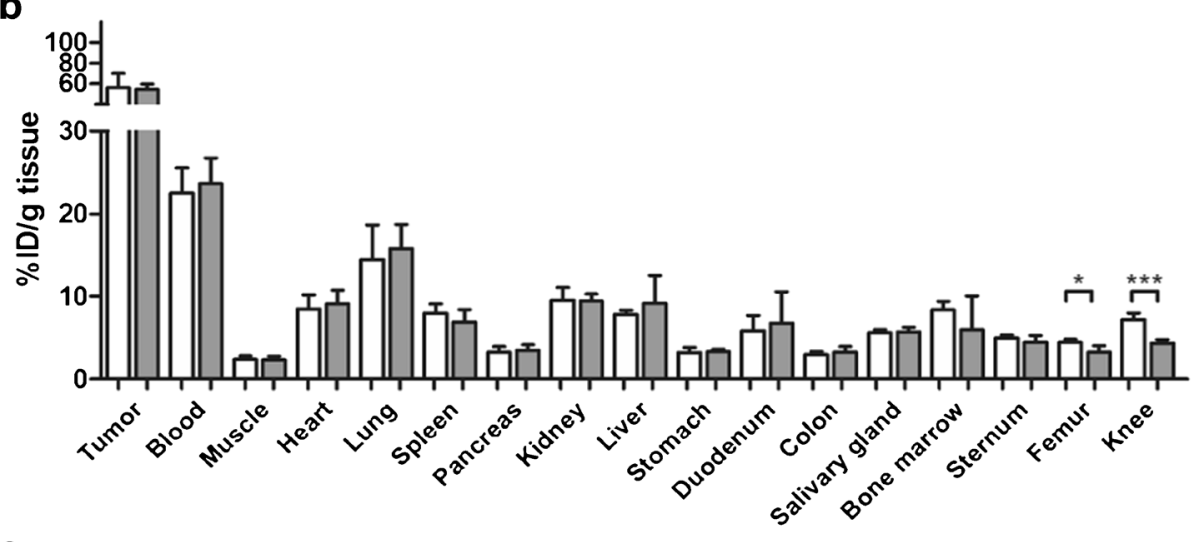

C
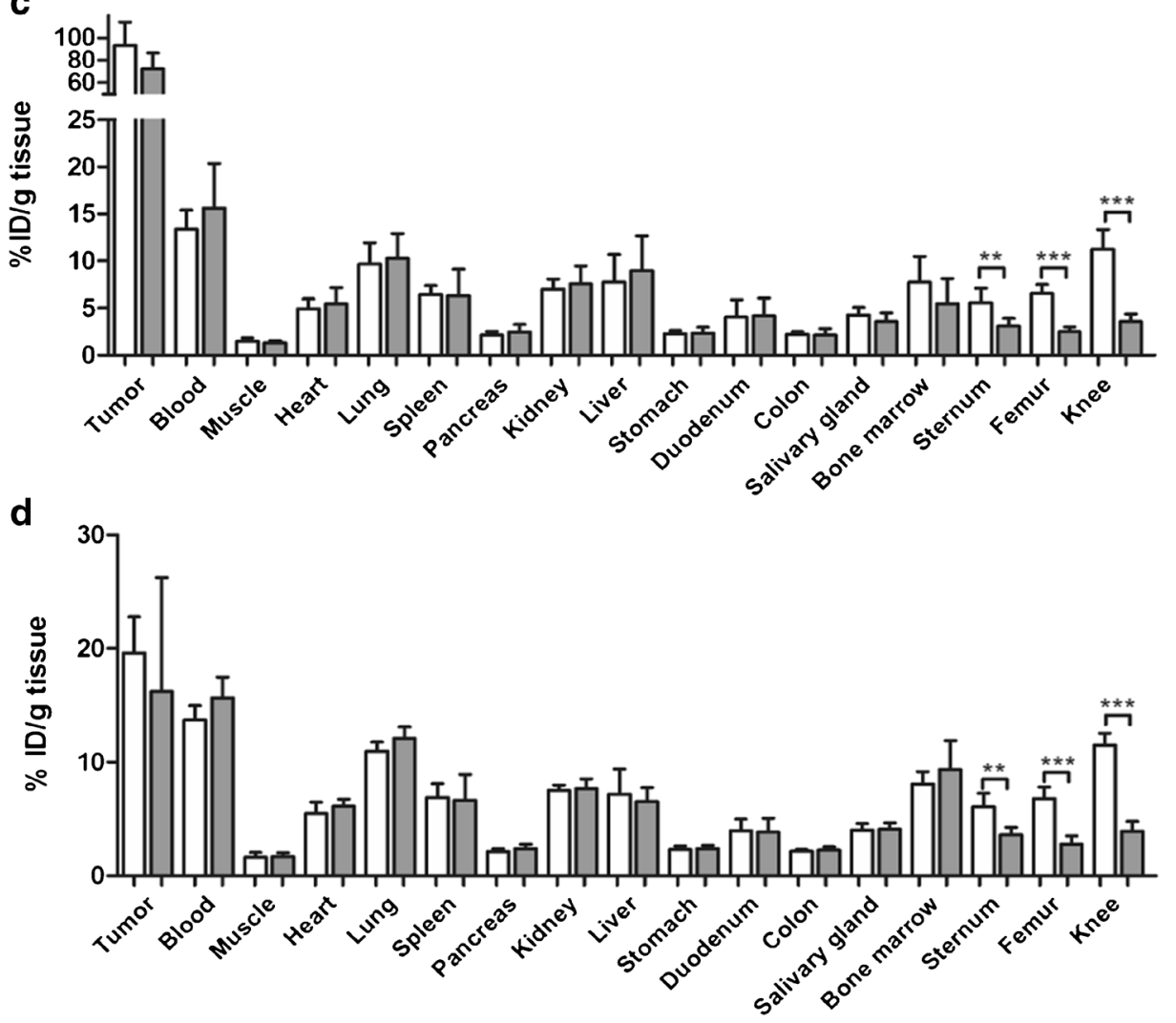

Fig. 4 Biodistribution of $\left[{ }^{89} \mathrm{Zr}\right] \mathrm{Zr}$-DFO-trastuzumab (white bars) and $\left[{ }^{89} \mathrm{Zr}\right] \mathrm{Zr}$-DFOcyclo*-trastuzumab ( grey bars) in HER2 ${ }^{+}$SKOV-3 tumour-bearing mice (a-c) at $24 \mathrm{~h} \mathrm{(a),} 72 \mathrm{~h}(\mathbf{b})$ and $168 \mathrm{~h}(\mathbf{c})$ after injection, and in HER2 ${ }^{-}$MDA-MB-231 tumour-bearing mice (d) at $168 \mathrm{~h}$ after injection. Bars represent means with standard deviations. ${ }^{*} p<0.05$, $* * p<0.01, * * * p<0.001$ 
uptake was significantly lower in mice injected with $\left[{ }^{89} \mathrm{Zr}\right] \mathrm{Zr}$ DFOcyclo*-trastuzumab.

\section{In vivo stability comparison to DFO*}

In a final experiment, the in vivo stability of $\left[{ }^{89} \mathrm{Zr}\right] \mathrm{Zr}$ DFO-trastuzumab and $\left[{ }^{89} \mathrm{Zr}\right] \mathrm{Zr}$-DFOcyclo*-trastuzumab were compared with that of $\left[{ }^{89} \mathrm{Zr}\right] \mathrm{Zr}$-DFO*-trastuzumab. Tumour uptakes were similar and not significantly different among the three conjugates (Fig. 5a). ${ }^{89} \mathrm{Zr}$ uptake in the femur and knee was significantly lower in mice injected with $\left[{ }^{89} \mathrm{Zr}\right] \mathrm{Zr}$-DFOcyclo*-trastuzumab and $\left[{ }^{89} \mathrm{Zr}\right] \mathrm{Zr}-\mathrm{DFO}^{*}$-trastuzumab than in mice injected with $\left[{ }^{89} \mathrm{Zr}\right] \mathrm{Zr}$-DFO-trastuzumab $(p<0.0001) .{ }^{89} \mathrm{Zr}$ uptake in the sternum was significantly lower in mice injected with $\left[{ }^{89} \mathrm{Zr}\right] \mathrm{Zr}$-DFOcyclo*-trastuzumab than in mice injected with $\left[{ }^{89} \mathrm{Zr}\right] \mathrm{Zr}$-DFO-trastuzumab $(p<0.0001)$, but not in mice injected with $\left[{ }^{89} \mathrm{Zr}\right] \mathrm{Zr}-\mathrm{DFO} *$ trastuzumab. Blood kinetics and uptake in all other tissues were similar among the three conjugates (Fig. 5b). Most importantly, PET images revealed bone uptake in mice injected with $\left.{ }^{89} \mathrm{Zr}\right] \mathrm{Zr}$-DFO-trastuzumab, but not in mice injected with $\left.{ }^{89} \mathrm{Zr}\right] \mathrm{Zr}$-DFOcyclo*-trastuzumab or $\left[{ }^{89} \mathrm{Zr}\right] \mathrm{Zr}$-DFO*-trastuzumab at $168 \mathrm{~h}$ after injection (Fig. 6).

\section{Discussion}

We report here a new ${ }^{89} \mathrm{Zr}$ chelator, DFOcyclo*, with improved in vitro and in vivo stability characteristics compared with currently the most common chelator used clinically, DFO. Because of the octacoordination obtained by the addition of a fourth cyclic hydroxamic acid group, DFOcyclo*

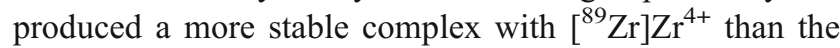
hexacoordinating chelator DFO. The results of competition assays with excess EDTA and DFO emphasized the improved stability of the complex indicated by easy ${ }^{89} \mathrm{Zr}$ release from DFO and DFO-trastuzumab, while it was significantly less easily released from DFOcyclo* and DFOcyclo*trastuzumab. The results of in vivo studies confirmed these findings, as indicated by significantly lower ${ }^{89} \mathrm{Zr}$ uptake in mineral bone following injection of ${ }^{89} \mathrm{Zr}$-DFOcyclo*trastuzumab. In a head-to-head comparison with DFO*, a related tetrahydroxamic DFO derivative with higher stability than the parent DFO as described by Vugts et al. [25], DFO* and DFOcyclo* showed similar in vitro and in vivo stability characteristics. Only when challenged with an excess of DFO in vitro (Fig. 2c) and in terms of sternum uptake in vivo (Fig. 5a), did DFOcyclo* outperform DFO*, suggesting that $\left[{ }^{89} \mathrm{Zr}\right] \mathrm{Zr}$-DFOcyclo* shows higher thermodynamic stability than $\left[{ }^{89} \mathrm{Zr}\right] \mathrm{Zr}$-DFO*. This higher stability can most likely be ascribed to the preorganization effect of the

Fig. 5 a Biodistribution of $\left[{ }^{89} \mathrm{Zr}\right] \mathrm{Zr}$-DFO-trastuzumab (white bars $),\left[{ }^{89} \mathrm{Zr}\right] \mathrm{Zr}$-DFOcyclo* trastuzumab (grey bars) and $\left[{ }^{89} \mathrm{Zr}\right] \mathrm{Zr}$-DFO*-trastuzumab (black bars) at $168 \mathrm{~h}$ after injection and blood kinetics. $\mathbf{b}$ Blood kinetics after injection in $\mathrm{HER}^{+}{ }^{+}$SKOV-3 tumour-bearing mice. Bars represent means with standard deviations. $* * *$ $p<0.0001$

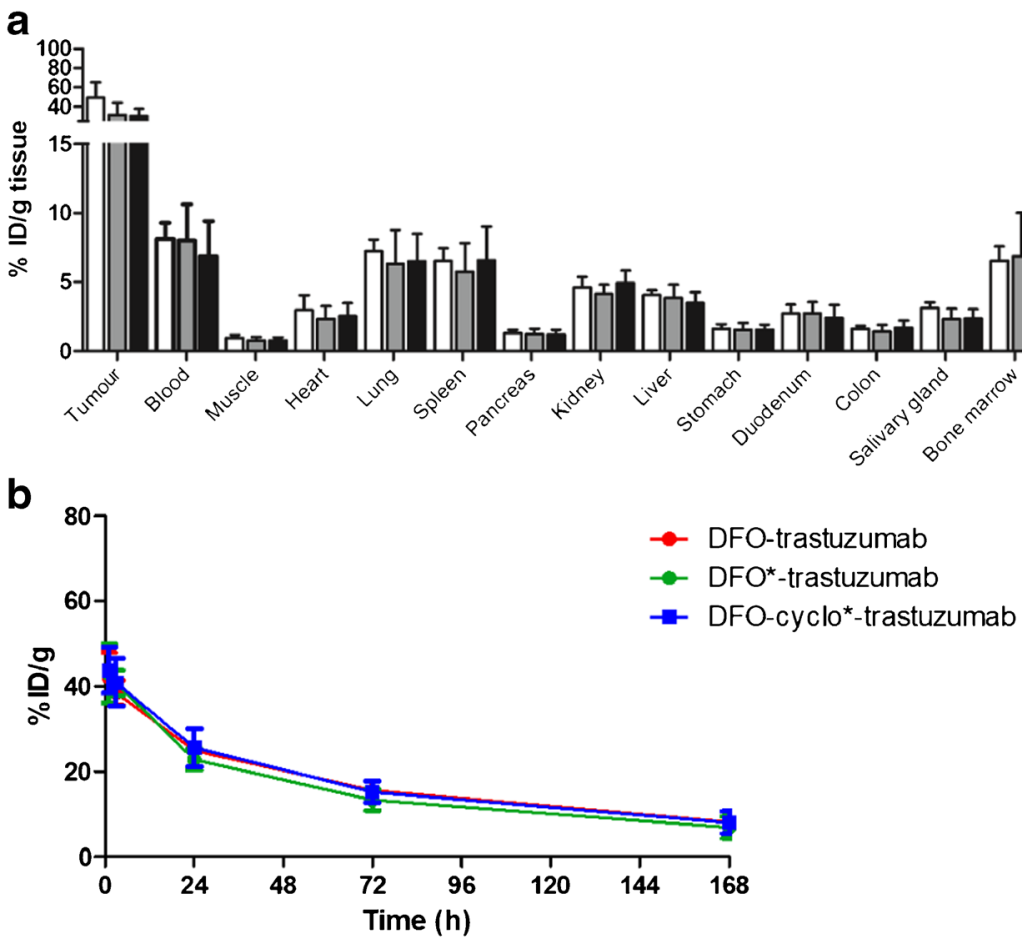


Fig. 6 PET images of mice injected with $\left.5 \mathrm{MBq}{ }^{89} \mathrm{Zr}\right] \mathrm{Zr}$ DFO-trastuzumab, $\left[{ }^{89} \mathrm{Zr}\right] \mathrm{Zr}$ DFOcyclo*-trastuzumab and $\left[{ }^{89} \mathrm{Zr}\right] \mathrm{Zr}$-DFO*-trastuzumab imaged at $168 \mathrm{~h}$ after injection
${ }^{89} \mathrm{Zr}$-DFOtrastuzumab

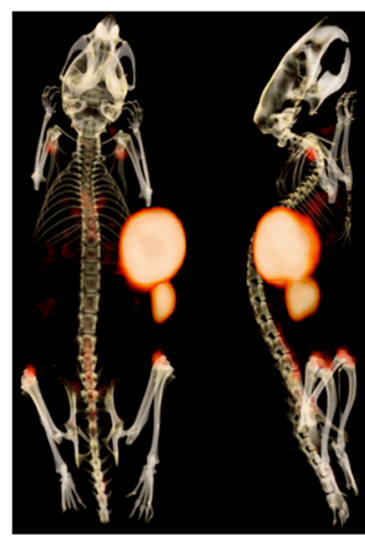

${ }^{89} \mathrm{Zr}$-DFOcyclo*. trastuzumab

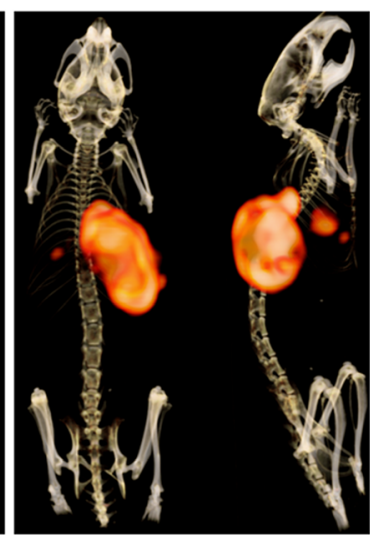

${ }^{89} \mathrm{Zr}$-DFO*-

trastuzumab

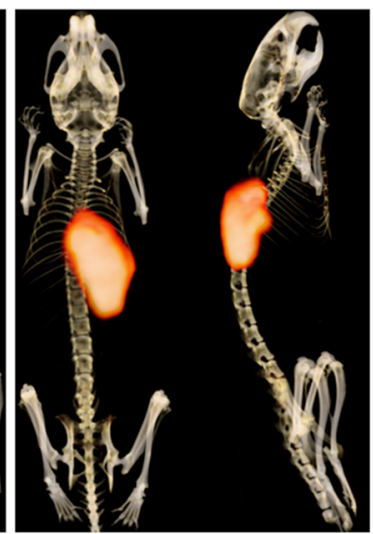

additional cyclic cis-hydroxamate binding unit found in DFOcyclo* as compared with the open-chain chelating motifs of DFO*.

In addition to DFO*, other chelating agents such as DFO squaramide ester, hydroxamic acid-based macrocycles, hydroxypyridinone (HOPO) derivatives, and DOTA have been proposed as alternatives to DFO for labelling antibodies with ${ }^{89} \mathrm{Zr}$. The DFO squaramide ester has the advantages of being more soluble in water and causing less aggregation of antibodies, and shows promising stability reflected by lower in vivo ${ }^{89} \mathrm{Zr}$ bone uptake at $24 \mathrm{~h}$ and $48 \mathrm{~h}$ after injection than DFO [13]. However, at a later time point ( $96 \mathrm{~h}$ after injection), the difference was not so pronounced, while in our study the difference in ${ }^{89} \mathrm{Zr}$ bone uptake between mice injected with $\left[{ }^{89} \mathrm{Zr}\right] \mathrm{Zr}$-DFOcyclo*-trastuzumab and $\left[{ }^{89} \mathrm{Zr}\right] \mathrm{Zr}$-DFOtrastuzumab increased over time, suggesting that $\left[{ }^{89} \mathrm{Zr}\right] \mathrm{Zr}$ DFOcyclo* has higher in vivo stability than $\left[{ }^{89} \mathrm{Zr}\right] \mathrm{Zr}$-DFO squaramide.

Besides DFO derivatives, macrocyclic chelators have also been tested as ${ }^{89} \mathrm{Zr}$ immunoPET agents. Zhai et al. and Summer et al. evaluated fusarinine $\mathrm{C}$, a cyclic siderophore containing three hydroxamic acid groups, conjugated to a cyclic RGD peptide, and an EGFR-binding Affibody, respectively $[15,35]$. While only offering hexacoordination for ${ }^{89} \mathrm{Zr}$ complexation, in vitro and in vivo results showed promising stability characteristics. Again, in their studies the follow-up time ( $24 \mathrm{~h}$ ) was too short for direct comparison of the results with those of our study, because we observed differences in bone uptake only beyond $72 \mathrm{~h}$ after injection. Another macrocyclic hydroxamic acid-based chelator with a hexadentate coordination was evaluated by Boros et al. [16]. Conjugated to trastuzumab, higher bone uptake was observed in mice injected with ${ }^{89} \mathrm{Zr}$-labelled trastuzumab through their newly developed chelate than labelled through DFO, indicating lower in vivo stability than DFO. Ma et al. tested a tripodal tris(hydroxypyridinone) ${ }^{89} \mathrm{Zr}$ chelate conjugated to trastuzumab in vivo, but also found increased ${ }^{89} \mathrm{Zr}$ bone uptake in mice injected with ${ }^{89} \mathrm{Zr}$-labelled trastuzumab through their new chelator compared to DFO, demonstrating lower in vivo stability [18].

Deri et al. proposed another octadentate ${ }^{89} \mathrm{Zr}$ chelator, 3,4,3-(LI-1,2-HOPO), consisting of four 1,2-HOPO units (aromatic counterpart of our 1,2-PIPOH) appended to a spermine backbone (referred to here as LI-HOPO) [19]. In vivo studies indicated that $\left[{ }^{89} \mathrm{Zr}\right] \mathrm{Zr}$-LI-HOPO-trastuzumab has higher stability than $\left[{ }^{89} \mathrm{Zr}\right] \mathrm{Zr}$-DFO-trastuzumab, as reflected by significantly lower bone uptake at later time points (168$336 \mathrm{~h}$ after injection). However, $\left.{ }^{89} \mathrm{Zr}\right] \mathrm{Zr}$-DFO-trastuzumab showed a higher tumour-to-blood uptake ratio, indicating that the in vivo HER2-targeting properties of $\left[{ }^{89} \mathrm{Zr}\right] \mathrm{Zr}$-LI-HOPOtrastuzumab may have been compromised. Another $\left[{ }^{89} \mathrm{Zr}\right] \mathrm{Zr}$ HOPO-trastuzumab conjugate, incorporating 2,3-HOPO chelating groups, was described by Tinianow et al. [20], but $\left[{ }^{89} \mathrm{Zr}\right] \mathrm{Zr}$ 2,3-HOPO-trastuzumab did not show higher stability than $\left[{ }^{89} \mathrm{Zr}\right] \mathrm{Zr}$-DFO-trastuzumab, as reflected by higher bone uptake in animals injected with $\left.{ }^{89} \mathrm{Zr}\right] \mathrm{Zr}-2,3-\mathrm{HOPO}$-trastuzumab. Pandya et al. evaluated the use of $\mathrm{H}_{4}$ DOTA as a chelator for $\left[{ }^{89} \mathrm{Zr}_{\mathrm{Z}} \mathrm{Zr}^{4+}\right.$ [24]. Despite [ $\left.{ }^{89} \mathrm{Zr}\right] \mathrm{Zr}$-DOTA showing promising higher in vivo stability than $\left[{ }^{89} \mathrm{Zr}\right] \mathrm{Zr}-\mathrm{DFO}$, DOTA may not be a suitable chelator for use in ${ }^{89} \mathrm{Zr}$ immunoPET, because of the harsh labelling conditions (incubation at $95{ }^{\circ} \mathrm{C}$ for $1 \mathrm{~h}$ ) that would disrupt the integrity of an antibody, requiring labelling before conjugation. Although comparing the results of the present study with those of previous studies investigating alternative ${ }^{89} \mathrm{Zr}$ immunoPET chelates is difficult, the present results suggest that $\left.{ }^{89} \mathrm{Zr}\right] \mathrm{Zr}^{4+}$ complexes with DFO* and DFOcyclo* show promising in vivo stability characteristics and therefore may be used as alternatives to DFO bioconjugates for ${ }^{89} \mathrm{Zr}$ immunoPET, as the latter chelator forms less-stable complexes.

The exact ${ }^{89} \mathrm{Zr}$ release mechanism from DFO bioconjugates is not yet fully understood. It has been hypothesized by Holland et al. that ${ }^{89} \mathrm{Zr}$-labelled metabolites enter the circulation after slow intratumoral metabolism [5]. In a study attempting to confirm this hypothesis, HER2 $2^{-}$tumour- 
bearing mice showed bone uptake after injection of ${ }^{89} \mathrm{Zr}$-labelled DFO-trastuzumab or DFOcyclo*-trastuzumab similar to that in HER $2^{+}$tumour-bearing mice, but about 4.5 times lower tumour uptake. This implies that with a fraction of the tumour uptake, and consequently only a fraction of intratumoral metabolism, ${ }^{89} \mathrm{Zr}$ is still being released from the DFO-trastuzumab at the same rate. We therefore hypothesize that ${ }^{89} \mathrm{Zr}$ is released from the chelator during physiological metabolism and is excreted via biological pathways rather than undergoing intratumoral metabolism.

\section{Conclusion}

The use of DFO as a chelator for ${ }^{89} \mathrm{Zr}$ immunoPET may result in undesired uptake of ${ }^{89} \mathrm{Zr}$ in mineral bone. ${ }^{89} \mathrm{Zr}$-labelled DFOcyclo* and DFOcyclo*-trastuzumab showed higher in vitro and in vivo stabilities than DFO and DFO-trastuzumab. DFOcyclo* is a highly promising candidate to become the new clinically used standard chelator for ${ }^{89} \mathrm{Zr}$ immunoPET.

Acknowledgments This study received funding from the Innovative Medicines Initiative 2 Joint Undertaking under grant agreement No 116106. This Joint Undertaking received support from the European Union's Horizon 2020 research and innovation program and EFPIA. In addition, this work was supported by the Centre National de la Recherche Scientifique (CNRS), the Université de Bourgogne (F.M. is grateful for a post-doctoral fellowship) and the Conseil Régional de Bourgogne Franche-Comté through the "Plan d'Action Régional pour l'Innovation" (program PARI), and by the European Union through the PO FEDER-FSE 2014/2020 Bourgogne program, Netherlands Organisation for Scientific Research (NWO, project number 91617039), and the Dutch Cancer Society (KWF, project number 10099).

\section{Compliance with ethical standards}

\section{Conflicts of interest None.}

Ethical approval All applicable international, national, and/or institutional guidelines for the care and use of animals were followed. This article does not describe any studies with human participants performed by any of the authors.

Open Access This article is distributed under the terms of the Creative Commons Attribution 4.0 International License (http:// creativecommons.org/licenses/by/4.0/), which permits unrestricted use, distribution, and reproduction in any medium, provided you give appropriate credit to the original author(s) and the source, provide a link to the Creative Commons license, and indicate if changes were made.

\section{References}

1. Verel I, Visser GW, Boerman OC, van Eerd JE, Finn R, Boellaard $\mathrm{R}$, et al. Long-lived positron emitters zirconium- 89 and iodine-124 for scouting of therapeutic radioimmunoconjugates with PET. Cancer Biother Radiopharm. 2003;18(4):655-61. https://doi.org/ $10.1089 / 108497803322287745$.
2. Perk LR, Visser GW, Vosjan MJ, Stigter-van Walsum M, Tijink BM, Leemans CR, et al. ${ }^{\left({ }^{(8)}\right.} \mathrm{Zr}$ as a PET surrogate radioisotope for scouting biodistribution of the therapeutic radiometals ${ }^{(90)} \mathrm{Y}$ and ${ }^{(177)} \mathrm{Lu}$ in tumor-bearing nude mice after coupling to the internalizing antibody cetuximab. J Nucl Med. 2005;46(11):1898-906.

3. Dijkers EC, Kosterink JG, Rademaker AP, Perk LR, van Dongen GA, Bart J, et al. Development and characterization of clinicalgrade $89 \mathrm{Zr}$-trastuzumab for HER2/neu immunoPET imaging. J Nucl Med. 2009;50(6):974-81. https://doi.org/10.2967/jnumed. 108.060392 .

4. Heskamp S, van Laarhoven HW, Molkenboer-Kuenen JD, Franssen GM, Versleijen-Jonkers YM, Oyen WJ, et al. ImmunoSPECT and immunoPET of IGF-1R expression with the radiolabeled antibody R1507 in a triple-negative breast cancer model. J Nucl Med. 2010;51(10):1565-72. https://doi.org/10. 2967/jnumed.110.075648.

5. Holland JP, Divilov V, Bander NH, Smith-Jones PM, Larson SM, Lewis JS. Zr-89-DFO-J591 for ImmunoPET of prostate-specific membrane antigen expression in vivo. J Nucl Med. 2010;51(8): 1293-300. https://doi.org/10.2967/jnumed.110.076174.

6. Laverman P, van der Geest T, Terry SY, Gerrits D, Walgreen B, Helsen MM, et al. Immuno-PET and immuno-SPECT of rheumatoid arthritis with radiolabeled anti-fibroblast activation protein antibody correlates with severity of arthritis. J Nucl Med. 2015;56(5): 778-83. https://doi.org/10.2967/jnumed.114.152959.

7. Abou DS, $\mathrm{Ku} \mathrm{T}$, Smith-Jones PM. In vivo biodistribution and accumulation of $89 \mathrm{Zr}$ in mice. Nucl Med Biol. 2011;38(5):675-81. https://doi.org/10.1016/j.nucmedbio.2010.12.011.

8. Heskamp S, Raave R, Boerman O, Rijpkema M, Goncalves V, Denat F. ${ }^{\left({ }^{89}\right)} \mathrm{Zr}$-Immuno-positron emission tomography in oncology: state-of-the-art ${ }^{(89)} \mathrm{Zr}$ radiochemistry. Bioconjug Chem. 2017;28(9):2211-23. https://doi.org/10.1021/acs.bioconjchem. $7 \mathrm{~b} 00325$.

9. Bhatt NB, Pandya DN, Wadas TJ. Recent advances in zirconium89 chelator development. Molecules. 2018;23(3):638. :https://doi. org $/ 10.3390 /$ molecules 23030638 .

10. Dilworth JR, Pascu SI. The chemistry of PET imaging with zirconium-89. Chem Soc Rev. 2018;47(8):2554-71. https://doi.org/10. 1039/C7CS00014F.

11. Patra M, Bauman A, Mari C, Fischer CA, Blacque O, Haussinger $\mathrm{D}$, et al. An octadentate bifunctional chelating agent for the development of stable zirconium-89 based molecular imaging probes. Chem Commun (Camb). 2014;50(78):11523-5. https://doi.org/10. 1039/c4cc05558f.

12. Allott L, Da Pieve C, Meyers J, Spinks T, Ciobota DM, KramerMarek G, et al. Evaluation of DFO-HOPO as an octadentate chelator for zirconium-89. Chem Commun. 2017;53(61):8529-32. https://doi.org/10.1039/c7cc03572a.

13. Rudd SE, Roselt P, Cullinane C, Hicks RJ, Donnelly PS. A desferrioxamine B squaramide ester for the incorporation of zirconium-89 into antibodies. Chem Commun. 2016;52(77): 11889-92. https://doi.org/10.1039/C6CC05961A.

14. Guerard F, Lee YS, Brechbiel MW. Rational design, synthesis, and evaluation of tetrahydroxamic acid chelators for stable complexation of zirconium(IV). Chem Eur J. 2014;20(19):5584-91. https:// doi.org/10.1002/chem.201304115.

15. Zhai C, Summer D, Rangger C, Franssen GM, Laverman P, Haas $\mathrm{H}$, et al. Novel bifunctional cyclic chelator for ${ }^{(89)} \mathrm{Zr}$ labelingradiolabeling and targeting properties of RGD conjugates. Mol Pharm. 2015;12(6):2142-50. https://doi.org/10.1021/acs. molpharmaceut.5b00128.

16. Boros E, Holland JP, Kenton N, Rotile N, Caravan P. Macrocyclebased hydroxamate ligands for complexation and immunoconjugation of ${ }^{(89)}$ zirconium for positron emission 
tomography (PET) imaging. Chempluschem. 2016;81(3):274-81. https://doi.org/10.1002/cplu.201600003.

17. Deri MA, Ponnala S, Zeglis BM, Pohl G, Dannenberg JJ, Lewis JS, et al. Alternative chelator for ${ }^{(89)} \mathrm{Zr}$ radiopharmaceuticals: radiolabeling and evaluation of 3,4,3-(LI-1,2-HOPO). J Med Chem. 2014;57(11):4849-60. https://doi.org/10.1021/jm500389b.

18. Ma MT, Meszaros LK, Paterson BM, Berry DJ, Cooper MS, Ma Y, et al. Tripodal tris(hydroxypyridinone) ligands for immunoconjugate PET imaging with ${ }^{(89)} \mathrm{Zr}^{(4+)}$ : comparison with desferrioxamine-B. Dalton Trans. 2015;44(11):4884-900. https:// doi.org/10.1039/c4dt02978j.

19. Deri MA, Ponnala S, Kozlowski P, Burton-Pye BP, Cicek HT, Hu $\mathrm{C}$, et al. P-SCN-Bn-HOPO: a superior bifunctional chelator for ${ }^{(89)} \mathrm{Zr}$ immunoPET. Bioconjug Chem. 2015;26(12):2579-91. https://doi.org/10.1021/acs.bioconjchem.5b00572.

20. Tinianow JN, Pandya DN, Pailloux SL, Ogasawara A, Vanderbilt AN, Gill HS, et al. Evaluation of a 3-hydroxypyridin-2-one (2,3HOPO) based macrocyclic chelator for ${ }^{(89)} \mathrm{Zr}(4+)$ and its use for immunoPET imaging of HER2 positive model of ovarian carcinoma in mice. Theranostics. 2016;6(4):511-21. https://doi.org/10. 7150/thno.14261.

21. Pandya DN, Pailloux S, Tatum D, Magda D, Wadas TJ. Dimacrocyclic terephthalamide ligands as chelators for the PET radionuclide zirconium-89. Chem Commun. 2015;51(12):2301-3. https://doi.org/10.1039/c4cc09256b.

22. Bhatt NB, Pandya DN, Xu JD, Tatum D, Magda D, Wadas TJ. Evaluation of macrocyclic hydroxyisophthalamide ligands as chelators for zirconium-89. PLoS One. 2017;12(6):e0178767. https:// doi.org/10.1371/journal.pone.0178767.

23. Buchwalder C, Rodriguez-Rodriguez C, Schaffer P, Karagiozov SK, Saatchi K, Hafeli UO. A new tetrapodal 3-hydroxy-4pyridinone ligand for complexation of ${ }^{(89)}$ zirconium for positron emission tomography (PET) imaging. Dalton Trans. 2017;46(29): 9654-63. https://doi.org/10.1039/c7dt02196h.

24. Pandya DN, Bhatt N, Yuan H, Day CS, Ehrmann BM, Wright M, et al. Zirconium tetraazamacrocycle complexes display extraordinary stability and provide a new strategy for zirconium-89-based radiopharmaceutical development. Chem Sci. 2017;8(3):2309-14. https://doi.org/10.1039/c6sc04128k.

25. Vugts DJ, Klaver C, Sewing C, Poot AJ, Adamzek K, Huegli S, et al. Comparison of the octadentate bifunctional chelator DFO*$p$ Phe-NCS and the clinically used hexadentate bifunctional chelator DFO- $p$ Phe-NCS for ${ }^{\left({ }^{89}\right)} \mathrm{Zr}$-immuno-PET. Eur J Nucl Med Mol Imaging. 2017;44(2):286-95. https://doi.org/10.1007/s00259-0163499-x.

26. Liu Y, Jacobs HK, Gopalan AS. A new approach to cyclic hydroxamic acids: intramolecular cyclization of N-benzyloxy carbamates with carbon nucleophiles. Tetrahedron. 2011;67(12): 2206-14. https://doi.org/10.1016/j.tet.2011.01.073.

27. Lindmo T, Boven E, Cuttitta F, Fedorko J, Bunn PA. Determination of the Immunoreactive fraction of radiolabeled monoclonal- antibodies by linear extrapolation to binding at infinite antigen excess. J Immunol Methods. 1984;72(1):77-89. https://doi.org/10. 1016/0022-1759(84)90435-6.

28. Birus M, Gabricevic M, Kronja O, Klaic B, van Eldik R, Zahl A. Kinetics and mechanism of the complexation of $\mathrm{La}^{3+}$ and $\mathrm{Cu}^{2+}$ ions with $N$-methylacetohydroxamic acid and desferrioxamine B. Inorg Chem. 1999;38(18):4064-9. https://doi.org/10.1021/ic990107r.

29. Sippl SP, Schenck HL. Conformational analysis of a secondary hydroxamic acid in aqueous solution by NOE spectroscopy. Magn Reson Chem. 2013;51(2):72-5. https://doi.org/10.1002/ mrc.3916.

30. Brandès S, Sornosa-Ten A, Rousselin Y, Lagrelette M, Stern C, Moncomble A, et al. Conformational and structural studies of $\mathrm{N}$ methylacetohydroxamic acid and of its mono- and bis-chelated uranium(VI) complexes. J Inorg Biochem. 2015;151:164-75. https://doi.org/10.1016/j.jinorgbio.2015.06.002.

31. Sornosa-Ten A, Jewula P, Fodor T, Brandès S, Sladkov V, Rousselin Y, et al. Effects of preorganization in the chelation of $\mathrm{UO}^{2+}$ by hydroxamate ligands: cyclic $\mathrm{PIPO}^{-}$vs. linear NMA. New J Chem. 2018;42(10):7765-79. https://doi.org/10.1039/ c8nj00166a.

32. Jewula P, Berthet JC, Chambron JC, Rousselin Y, Thuéry P, Meyer M. Synthesis and structural study of tetravalent $\left(\mathrm{Zr}^{4+}, \mathrm{Hf}^{4+}, \mathrm{Ce}^{4+}\right.$, $\mathrm{Th}^{4+}, \mathrm{U}^{4+}$ ) metal complexes with cyclic hydroxamic acids. Eur J Inorg Chem. 2015;9:1529-41. https://doi.org/10.1002/ejic. 201403206.

33. Vosjan MJWD, Perk LR, Visser GWM, Budde M, Jurek P, Kiefer $\mathrm{GE}$, et al. Conjugation and radiolabeling of monoclonal antibodies with zirconium-89 for PET imaging using the bifunctional chelate p-isothiocyanatobenzyl-desferrioxamine. Nat Protoc. 2010;5(4): 739-43. https://doi.org/10.1038/nprot.2010.13.

34. Deri MA, Zeglis BM, Francesconi LC, Lewis JS. PET imaging with Zr-89: from radiochemistry to the clinic. Nucl Med Biol. 2013;40(1):3-14. https://doi.org/10.1016/j.nucmedbio.2012.08. 004.

35. Summer D, Garousi J, Oroujeni M, Mitran B, Andersson KG, Vorobyeva A, et al. Cyclic versus noncyclic chelating scaffold for Zr-89-labeled ZEGFR:2377 Affibody bioconjugates targeting epidermal growth factor receptor overexpression. Mol Pharm. 2018;15(1):175-85. https://doi.org/10.1021/acs.molpharmaceut. $7 \mathrm{~b} 00787$.

Publisher's note Springer Nature remains neutral with regard to jurisdictional claims in published maps and institutional affiliations. 